\title{
Administracja zespolona w mieście na prawach powiatu
}

\author{
\# administracja \# administracja zespolona \# miasto na prawach powiatu \\ \# powiat \# zwierzchnictwo \# podporządkowanie
}

\# administration \# combined administration \# city of under law of the county

\# powiat \# authority \# subordination

Artykuł porusza problematykę funkcjonowania organów administracji zespolonej w mieście na prawach powiatu. We wstępie tekstu wskazano na powiązania między restytucją samorządu terytorialnego w Polsce i wprowadzeniem jego trójstopniowego modelu a wykonywaniem zadań terenowej administracji rządowej. Następnie odniesiono się do kwestii modelowej struktury powiatowej administracji zespolonej, która została ujęta w ustawie o samorządzie powiatowym. Szczególną uwagę poświęcono staroście jako organowi administracji ogólnej, z którym zespolono poszczególne powiatowe jednostki organizacyjne. W dalszej części poddano analizie odmienności w strukturze administracji zespolonej w mieście na prawach powiatu. Kluczowym zagadnieniem artykułu jest analiza art. 33b ustawy o samorządzie powiatowym w kontekście odmienności ustrojowych gminy o statusie miasta. Dokonano również analizy poszczególnych organów administracji zespolonej w mieście na prawach powiatu, prezentując wcześniejszy stan normatywny, jak i formułując uwagi de lege lata. Publikację kończy podsumowanie organizacji administracji zespolonej w tej specyficznej jednostce samorządu terytorialnego.

The article discusses the problem of functioning of the combined administration bodies in cities on county rights. In the preface, the relationship between restitution of local government in Poland and introduction of its three-level model and performing tasks of government territorial administration, is indicated. Later on, the Autor addresses to a model structure of county combined administration bodies, which was regulated in the Act on county government (later referred to as the "Act"). A particular attention was given to the county foreman, as a general

Miasto. Pamięć i Przyszłość 3/2 (2018) ISSN 2543-621X

\section{OPEN ACCESS}

Citation: Barański M., Administracja zespolona w mieście na prawach powiatu ${ }_{\mu \prime}$ Miasto. Pamięć i Przyszłość", $3 / 2$ (2018).

https://doi.org/10.26774/mpp.78

Editor: Jerzy Korczak

Received: October, 2018

Accepted: December, 2018

Published: December, 2018

Copyright: @ Ośrodek „Pamięć i Przyszłość" This is an open access article distributed under the terms of the Creative Commons Attribution-ShareAlike Licence, which permits unrestricted use, distribution, and reproduction in any medium, provided the original author and source are credited, with indications if any changes are made. All derivative works must be licensed under the same licence. 
administration body, with whom each of the county organization units is connected. Then, the author analyses the diversities between different combined administration structures in cities on county rights. The key issue of the article is the analysis of article 33b of the Act, in context of system differences of municipality with the status of city. Author also analyses particular combined administration bodies in the city of county rights, presenting previous normative state, and formulating de lege lata remarks. Summary of the article describes combined administration government in this specific local government unit.

Mateusz Barański - student stacjonarnych studiów na kierunku prawo na Wydziale Prawa, Administracji i Ekonomii Uniwersytetu Wrocławskiego, członek Koła Naukowego Prawa Publicznego "Imperium”. 


\section{Wstęp}

Przemiany ustrojowe i społeczne, które miały miejsce w Polsce na początku lat 9o. ubiegłego stulecia, pozostawiły wyraźny ślad również w prawie administracyjnym. Aktem prawnym, który wprowadził w życie regulacje nadające nowy kształt państwu, była uchwalona w 1997 r. Konstytucja RP. Uregulowano w niej m.in. kwestię samorządu terytorialnego. Ustrojodawca ustanowił gminę obligatoryjną i podstawową jednostką samorządową, ale równocześnie pozostawił możliwość tworzenia innych w drodze ustawy. Ta regulacja zdeterminowała dalsze prace legislacyjne, których rezultatem było przyjęcie trójstopniowego modelu samorządu terytorialnego oraz uchwalenie w 1998 r. ustaw o samorządzie powiatowym i samorządzie województwa².

Przygotowania do wdrożenia nowego rozwiązania ustrojowego rozpoczęły się jednak kilka lat wcześniej. Już w 1994 r. tzw. program pilotażowy miał na celu sprawdzenie możliwości utworzenia powiatów poprzez przekazanie

Miasto. Pamięć i Przyszłość 3/2 (2018) ISSN 2543-621X największym polskim miastom określonych zadań z zakresu administracji rządowej, wraz z odpowiednimi środkami finansowymi³. Starano się stwarzać warunki zapewniające decentralizację władzy publicznej w praktyce. Z dniem 1 stycznia 1999 r. zaczęły obowiązywać regulacje związane z reformą administracyjną.

Reminiscencją wprowadzenia trójstopniowego modelu samorządu terytorialnego było utworzenie podziału na centralną administrację rządową oraz administrację rządową w terenie. W świetle obecnie obowiązującej Konstytucji RP, Rada Ministrów prowadzi politykę wewnętrzną państwa, zaś jej przedstawicielem w województwie jest wojewoda. Z tej regulacji wynika, iż wspólnoty samorządowe nie mają nieograniczonej swobody w stanowieniu. Należy pamiętać, że samorząd terytorialny wykonuje zadania publiczne, których konstytucja lub ustawy nie zastrzegają dla organów innych władz publicznych.

Miasto na prawach powiatu to szczególny przypadek skomplikowanej instytucji prawnej.

1. Dz. U. Nr 78 poz. 483 z późn. zm.

2. Prawo administracyjne, red. J. Boć, Wrocław 2010, s. 193.

3. A. Wierzbica, Miasto na prawach powiatu. Zagadnienia ustrojowe, Warszawa 2006, s. 26. 
Pierwotna regulacja ustawy z dnia 5 czerwca 1998 r. o samorządzie powiatowym 4 nie określała jednoznacznie jaki charakter ma ta jednostka samorządowa. Dopiero nowelizacja u.s.p. z 2001 r. pozwoliła bezspornie ustalić, iż miasta na prawach powiatu są gminami, którym przysługują prawa powiatu ${ }^{5}$. Kluczowe stało się odesłanie w kwestii ustroju i działania organów miasta na prawach powiatu do ustawy o samorządzie gminnym (art. 92 ust. 3 u.s.p.).

\section{Zagadnienie administracji zespolonej}

W potocznym rozumieniu pojęcie administracji odpowiada jego łacińskiemu sformułowaniu ministrare, które jest synonimem pomocy, służby, kierownictwa czy zarządu ${ }^{6}$. Należy jednak wskazać, iż w samej doktrynie istnieje bardzo wiele definicji opierających się na akcentowaniu funkcji, czy też celów działania administracji. Zaspokajanie potrzeb obywateli, często uznawane za meritum funkcjonowania organów państwowych, doznaje jednak wielu podziałów. W demokratycznym państwie prawnym istotne jest partycypowanie społeczeństwa w sprawowaniu władzy. Gwarancją takiego stanu rzeczy jest m.in. działalność administracji samorządowej. Niemniej jednak, jak już wcześniej wspomniano, administracja rządowa realizuje swoje kompetencje także w ponadgminnych jednostkach samorządu terytorialnego. Właśnie

\footnotetext{
4. Dz. U. z 2018 r. poz. 995 z późn. zm., dalej jako u.s.p.

5. Prawo..., s. 214.

6. Tamże, s. 12.

7. Dz. U. z 2001 r. Nr 80 poz. 872.
}

8. Ustawa o samorządzie powiatowym. Komentarz, red. B. Dolnicki, Kraków 2005, s. 258.

9. I. Lewandowska-Malec, Samorzad terytorialny w Polsce. Zarys wykładu, kazusy, wybór źródet, Kraków 2007, s. 58. te dwa podsystemy składają się na administrację terenową.

Pojęcie rządowej administracji zespolonej i rządowej administracji niezespolonej w polskim systemie prawnym po raz pierwszy wprowadziła regulacja obecnie już nieobowiązującej ustawy z 5 czerwca 1998 r. o administracji rządowej w województwie?. Zgodnie z jej treścią, wojewoda jest zwierzchnikiem oraz przedstawicielem rządowej administracji zespolonej w województwie (art. 3.). Przytoczona regulacja determinuje działanie innych jednostek organizacyjnych na tym szczeblu. Warto jednak pamiętać, że samo rozróżnianie i przeciwstawianie sobie administracji zespolonej i niezespolonej ma znacznie dłuższą historię. Uzasadnienia dla takiego podziału poszukiwano wszystkim w rosnących zadaniach administracji, zwiększaniu się stopnia jej specjalizacji, a także pojawieniu się funkcji policyjnych, bardzo szczegółowych i konkretnych (np. policji rolnej)8.

Zespolenie zakłada odpowiedzialność jednego organu właściwości ogólnej za prawidłowe wykonanie zadań innych jednostek w danej sferze działalności administracji. Istotne znaczenie ma tutaj także współpraca poszczególnych ogniw. Wskazuje się na różne rodzaje zespolenia - organizacyjne, kompetencyjne, czy też finansowe. Do organu należy także personalna obsada stanowisk kierowniczych9. Zespolenie organizacyjne zakłada włączenie jednostek zespolonych do urzędu obsługującego organ właściwości ogólnej. Zespolenie kompetencyjne pozwala temu organowi na wykonywanie

Miasto. Pamięć i Przyszłość 3/2 (2018) ISSN 2543-621X 
zadań osobiście albo przy pomocy kierowników podległych jednostek. Z kolei zespolenie finansowe oznacza włączenie budżetów jednostek zespolonych do budżetu zwierzchnika. Organy administracji rządowej w terenie, które wykonują swoje zadania poza opisaną strukturą oraz podlegają właściwemu ministrowi lub centralnemu organowi administracji rządowej, tworzą rządową administrację niezespoloną.

Analizując działalność administracji zespolonej, należy zwrócić uwagę na kwestię zwierzchnictwa. Ustawodawca nie stworzył definicji legalnej tego pojęcia, istnieją również trudności z wyodrębnieniem jego szczególnych cech. Jan Zimmermann określenia tego pojęcia poszukuje w ustawie z dnia 23 stycznia 2009 r. o wojewodzie i administracji rządowej w województwie ${ }^{10}$, która wskazuje kompetencje wojewody. Zgodnie z jej art. 51 zwierzchnictwo to jednocześnie kompetencje kierownicze, koordynacyjne i kontrolne ${ }^{11}$. Wśród wymienionych najbardziej znaczące wydaje się być kierownictwo. Zasadniczo wyposaża ono organ zwierzchni do wydawania poleceń nakazujących realizację określonego działania, bez określania sposobu i trybu. Oznacza to, że za uszczegółowienie polecenia odpowiada kierownik danej jednostki.

\section{Struktura administracji zespolonej w mieście na prawach powiatu}

Na stopniu powiatowym zespolenie określane jest jako powiatowa administracja rządowa. Przesądza o tym fakt, iż na tym stopniu nie wyodrębniono organizacyjnie administracji

Miasto. Pamięći Przyszłość 3/2 (2018) ISSN 2543-621X 55 rządowej, w przeciwieństwie do województwa ${ }^{12}$. Zadania powiatu wykonywane są przez zarząd powiatu przy pomocy starostwa powiatowego oraz jednostek organizacyjnych powiatu, w tym powiatowego urzędu pracy (art. 33 u.s.p.). Z kolei zgodnie z art. 33b u.s.p. powiatową administrację zespoloną stanowią:

1) starostwo powiatowe;

2) powiatowy urząd pracy, będący jednostką organizacyjną powiatu;

3) jednostki organizacyjne stanowiące aparat pomocniczy kierowników powiatowych służb, inspekcji i straży.

Warto zwrócić uwagę, iż wymienione w tym przepisie jednostki stanowią połączenie elementów samorządowych i rządowych, co ma związek ze wspominanym brakiem organizacyjnego wyodrębnienia administracji rządowej na stopniu powiatowym ${ }^{13}$.

Zwierzchnikiem powiatowych służb, inspekcji i straży jest starosta, który również organizuje prace zarządu powiatu i starostwa powiatowego oraz reprezentuje powiat na zewnątrz. Kierownicy powiatowych służb, inspekcji i straży wykonują określone w ustawach zadania i kompetencje przy pomocy jednostek organizacyjnych - komend i inspektoratów (art. 33a ust. 1 u.s.p.). W przytoczonym przepisie przejawia się jeszcze jedna kompetencja starosty, mianowicie składanie wojewodzie wniosku co do tworzenia, przekształcania lub likwidowania tych jednostek. Niezależnie od zespolenia organów służb, inspekcji i straży ze starostą, pozostają

10. Dz. U. z 2017 r. poz. 2234 z późn. zm.

11. J. Zimmermann, Prawo administracyjne, Warszawa 2014, s. 209.

12. Prawo..., s. 161.

13. Ustawa.., s. 262. 
one organami administracji rządowej, a zatem wykonując poszczególne zadania powiatu, czynią to we własnym imieniu i mają do dyspozycji własny aparat pomocniczy ${ }^{14}$.

Odmienności organizacyjne administracji zespolonej w mieście na prawach powiatu wynikają przede wszystkim z różnic ustrojowych. W tym przypadku mamy monokratyczny organ wykonawczy, którym jest prezydent miasta. Sprawuje on jednocześnie funkcję zwierzchnika służbowego w stosunku do kierowników miejskich jednostek organizacyjnych, służb, inspekcji oraz straży ${ }^{15}$. Prezydent miasta pełni funkcję starosty w warunkach ustrojowych o charakterze bezwzględnie powiatowym, co wynika z faktu, że będąca organem stanowiący rada miasta nie może go odwołać. Pogląd ten podzielił Trybunał Konstytucyjny w swoim wyroku z dnia 11 stycznia 2000 r. Trybunał uznał, że prezydent miasta na prawach powiatu pełni jednocześnie funkcję starosty, a w związku z tym otrzymał szereg nowych kompetencji z zakresu administracji rządowej i w tym zakresie jego sytuacja jest identyczna jak wszystkich innych starostów ${ }^{16}$. Zwierzchnictwo prezydenta miasta w stosunku do powiatowych (miejskich) służb, inspekcji i straży przejawia się w możliwości powoływania i odwoływania kierowników tych jednostek (po uzgodnieniu z wojewodą), zatwierdzaniu programów ich działania oraz uzgadnianiu wspólnej działalności jednostek na terenie miasta na

14. Tamże, s. 263.

15. B. Dolnicki, Samorzad terytorialny, Warszawa 2016, s. 184.

16. Dz. U. z 2000 r. Nr 3 poz. 45.

17. Dz. U. z 2018 r. poz. 994 z późn. zm.

18. A. Wierzbica, dz. cyt., s. 135.

19. B. Dolnicki, dz. cyt., s. 187. prawach powiatu. Istotne jest zwrócenie uwagi na tzw. podwójne podporządkowanie, które dotyczy służb, inspekcji i straży. Polega ono na równoczesnej podległości organów zespolonych władzy samorządowej w postaci prezydenta miasta oraz władzy rządowej, której zadania w terenie wykonuje wojewódzki inspektor lub komendant.

Prezydent miasta na prawach powiatu wykonuje zadania przy pomocy urzędu miasta. Pełni on także funkcję zwierzchnika służbowego w stosunku do pracowników urzędu oraz określa zasady i organizację funkcjonowania urzędu w drodze zarządzenia. Pewne wątpliwości budzi właśnie ta forma aktu prawnego. Zgodnie z przepisami ustawy z dnia 8 marca 1990 r. o samorządzie gminnym77, podstawowym aktem prawnym w zakresie organizacji instytucji i urzędów gminnych jest uchwała, zaś zarządzenia wydawane są w przypadkach niecierpiących zwłoki. W doktrynie wskazuje się, że analizowane zarządzenie prezydenta nie jest objęte przepisami ustawy gminnej ani nie stanowi decyzji administracyjnej w rozumieniu Kodeksu postępowania administracyjnego (Podgórski, Wierzbica). Zasadne wydaje się być powołanie na art. 93 Konstytucji RP, zgodnie z którym zarządzenia mają charakter wewnętrzny i obowiązują tylko jednostki organizacyjne podległe organowi, który je wydaje - w tym przypadku będą to pracownicy urzędu miasta ${ }^{18}$. Status prawny pracowników urzędu miasta na prawach powiatu został określony w przepisach o pracownikach samorządowych ${ }^{19}$. Jan Boć

Miasto. Pamięć i Przyszłość 3/2 (2018) ISSN 2543-621X 
zwraca uwagę na fakt, iż do realizacji zespolenia na szczeblu powiatowym nie jest konieczne zespolenie finansowe. Co więcej, również w tym wypadku zespolenie kompetencyjne wydaje się być stosunkowo słabe, ponieważ kierownicy powiatowych służb, inspekcji i straży działają zawsze w swoim imieniu²0.

Powiatowe urzędy pracy funkcjonują na podstawie ustawy z dnia 20 kwietnia 2004 r. o promocji zatrudnienia i instytucjach rynku pracy ${ }^{21}$. Jednostki te są powoływane do realizacji określonych w ustawie zadań z zakresu polityki rynku pracy na terenie danego powiatu. W mieście na prawach powiatu organem zatrudnienia w rozumieniu ustawowym jest prezydent miasta, zaś powiatowy urząd pracy prowadzi obsługę jego działalności. Utworzenie, likwidacja lub zmiana obszaru działania powiatowego urzędu pracy wymaga zgody ministra właściwego do spraw pracy. W art. 9 ust. 5 ustawy o promocji zatrudnienia i instytucjach rynku pracy uregulowano tryb powoływania i odwoływania dyrektora powiatowego urzędu pracy. Prezydent miasta na prawach powiatu powołuje dyrektora urzędu po przeprowadzeniu obligatoryjnego konkursu. Trzeba spełnić szereg warunków wymienionych expressis verbis w ustawie, mianowicie kandydat na stanowisko dyrektora powiatowego urzędu pracy musi posiadać wykształcenie wyższe oraz co najmniej 3-letni staż pracy w publicznych służbach zatrudnienia lub co najmniej 5-letni staż pracy w innych instytucjach rynku pracy. Prezydent miasta odwołuje dyrektora powiatowego

Miasto. Pamięć i Przyszłość 3/2 (2018) ISSN 2543-621X urzędu pracy po uzyskaniu opinii powiatowej rady rynku pracy. Rzeczona opinia nie jest wymagana w sytuacjach, w których zgodnie z przepisami Kodeksu pracy, pracodawca może rozwiązać z pracownikiem umowę o pracę bez wypowiedzenia oraz w przypadku odwołania dyrektora powiatowego urzędu pracy na jego wniosek. Prezydent miasta może, w formie pisemnej, upoważnić dyrektora powiatowego urzędu pracy lub innych pracowników tego urzędu (na wniosek dyrektora) do załatwiania w imieniu starosty spraw, w tym do wydawania decyzji, postanowień oraz zaświadczeń w trybie przepisów o postępowaniu administracyjnym.

\section{Status prawny zespolonych służb, inspekcji i straży}

Struktura administracji zespolonej w miastach na prawach powiatu pierwotnie została uformowana w innym kształcie niż w aktualnym stanie prawnym. Przed 1999 r. toczyło się wiele dyskusji na temat warunków organizacyjnoprawnych i majątkowych przyszłych struktur administracyjnych. Kapitalne znaczenie dla statusu miast na prawach powiatu miała ustawa z dnia 13 października 1998 r. - Przepisy wprowadzające ustawy reformujące administrację publiczną 22. Zgodnie z jej treścią, urzędy rejonowe w miastach na prawach powiatu, w których nie było siedziby władz innego powiatu, weszły w skład urzędu miasta. Z dniem 1 stycznia 1999 r. w miastach będących siedzibą władz miasta na prawach powiatu i powiatu mającego siedzibę

20. Powiat. Z teorii, kompetencje, komentarz, red. J. Boć, Wrocław 2001, s. 40.

21. Dz. U. z 2018 r. poz. 1265 z późn. zm.

22. Dz. U. Nr 133 poz. 872 z późn. zm., dalej jako Przepisy wprowadzające. 
władz w tym mieście, miejskimi jednostkami organizacyjnymi wykonującymi zadania na obszarze tego miasta i powiatu stały się (art. 17 Przepisów wprowadzających):

1) Komenda rejonowa Państwowej Straży Pożarnej;

2) komenda rejonowa Policji;

3) rejonowy inspektorat weterynarii;

4) terenowa stacja sanitarno-epidemiologiczna. Przewidziano wyjątek od tej generalnej zasady, mianowicie w miastach liczących więcej niż 700 tys. mieszkańców i będących siedzibami władz powiatu utworzono powiatową, a nie miejską, komendę Policji (art. 30 ust. 2 Przepisów wprowadzających). Dodatkowo, z dniem 1 stycznia 1999 r., w miastach na prawach powiatu utworzono powiatowe inspektoraty nadzoru budowlanego. Pewne wątpliwości budziła tutaj kwestia nazewnictwa. W tym przypadku nie ma zastosowania rozróżnienie „powiatowej” czy "miejskiej” służby, inspekcji i straży, o czym przesądza art. 40 Przepisów wprowadzających.

Strukturę i funkcjonowanie administracji zespolonej w mieście na prawach powiatu determinują przepisy materialnoprawne dotyczące poszczególnych jednostek oraz ustawy samorządowe i Przepisy wprowadzające. Przedstawiony wcześniej stan uległ częściowej zmianie na skutek nowelizacji ustaw szczególnych. W wyniku działań legislacyjnych do powiatowej

23. A. Wierzbica, dz. cyt., s. 137.

24. Ustawa z dnia 24 sierpnia 2001 r. o zmianie ustawy o Państwowej Inspekcji Sanitarnej oraz niektórych ustaw (Dz. U. Nr 128 poz. 1407 z późn. zm.)

25. Ustawa z dnia 23 stycznia 2009 r. o zmianie niektórych ustaw w związku ze zmianami w organizacji i podziale zadań administracji publicznej w województwie (Dz. U. Nr 92 poz. 753 z późn. zm.) 26. Prawo administracyjne. Część ogólna, red. J. Chmaj, Warszawa 2007, s. 254. administracji zespolonej od 2004 r. nie należy już powiatowy inspektor weterynarii, który stał się organem rządowej administracji niezespolonej²3. Zmieniała się także sytuacja stacji sanitarno-epidemiologicznych. Z dniem 1 stycznia 2002 r. organy inspekcji sanitarnej zostały wyłączone z zespolonej administracji rządowej w terenie na skutek zmiany ustawy o Inspekcji Sanitarnej24. Od dnia 1 kwietnia 2009 r. powiatowe stacje sanitarno-epidemiologiczne ponownie znajdują się w strukturze zespolonej w wyniku zmian w organizacji i podziale zadań administracji publicznej w województwie 25 .

Terytorialny zasięg działania zespolonych służb, inspekcji i straży co do zasady obejmuje obszar całego miasta na prawach powiatu. W przypadku, gdy w tym samym mieście na prawach powiatu znajduje się siedziba władz innego powiatu, jednostki organizacyjne ex lege wykonują zadania na obszarze miasta na prawach powiatu i powiatu. Ustawodawca stworzył jednak w art. 73 u.s.p. możliwość zawierania przez powiaty porozumień w sprawie powierzenia jednemu z nich prowadzenia zadań publicznych. Do takiego porozumienia, w zakresie nieuregulowanym odrębnie, stosuje się odpowiednio przepisy dotyczące związków powiatów. Samo porozumienie należy do niewładczych form działania administracji. To czynność z zakresu prawa administracyjnego, której stronami są podmioty wykonujące administrację publiczną, zaś istotą tej czynności jest zgodne oświadczenie woli tych podmiotów ${ }^{26}$. Organem uprawnionym do zawierania takich porozumień

Miasto. Pamięć i Przyszłość 3/2 (2018) ISSN 2543-621X 
jest starosta lub prezydent miasta. W praktyce bardzo często spotykane są porozumienia powiatów graniczących z miastami na prawach powiatu oraz tych miast, na mocy których miejskie służby, inspekcje i straże przejmują do realizacji zadania o charakterze publicznym. Uprawienie do powoływania i odwoływania kierowników takich jednostek przyznano wspólnie, na zasadzie porozumienia, staroście i prezydentowi miasta na prawach powiatu. W przypadku braku porozumienia między zainteresowanymi władzami lokalnymi, uprawnienie to przynależy do wojewody ${ }^{27}$

W aktualnym stanie prawnym administrację zespoloną w mieście na prawach powiatu tworzą następujące służby, inspekcje i straże:

1) komenda miejska Policji;

2) komenda miejska Państwowej Straży Pożarnej;

3) powiatowy inspektorat nadzoru budowlanego;

4) powiatowa stacja sanitarno-epidemiologiczna. Pozycja prawna komendanta miejskiego Policji została uregulowana w ustawie z dnia 6 kwietnia 1990 r. o Policji28. Jest to organ właściwy w sprawach ochrony bezpieczeństwa ludzi oraz utrzymania bezpieczeństwa i porządku publicznego na terenie miasta na prawach powiatu. Komendanta miejskiego Policji powołuje i odwołuje komendant wojewódzki Policji, po zasięgnięciu opinii prezydenta miasta. Opinia ta nie ma takiego charakteru, jaki przepisy u.s.p. przewidują w kwestii zwierzchnictwa prezydenta miasta nad służbami, inspekcjami i strażami29. Co więcej, nie ma ona charakteru wiążącego.

Miasto. Pamięć i Przyszłość 3/2 (2018) ISSN 2543-621X 59
W tym przypadku dochodzi do ograniczenia zakresu zespolenia osobowego, wynikającego z u.s.p., przepisami ustawy szczególnej. Oprócz tego, komendant wojewódzki Policji jest organem wyższego stopnia nad komendantem miejskim Policji w rozumieniu przepisów o postępowaniu administracyjnym. Komendant miejski Policji wykonuje swoje zadania przy pomocy podległej mu komendy miejskiej.

Stosunkowo podobna jest regulacja ustawy z dnia 24 sierpnia 1991 r. o Państwowej Straży Pożarnej30, która określa organizację i funkcjonowanie komendy miejskiej, jako jednostki organizacyjnej Państwowej Straży Pożarnej. Istotna różnica zachodzi w trybie powoływania i odwoływania komendanta miejskiego. Zgodnie z art. 13 ustawy owego powołania i odwołania dokonuje komendant wojewódzki Państwowej Straży Pożarnej, lecz w porozumieniu z prezydentem miasta na prawach powiatu. Ponownie widać tutaj ograniczenie zespolenia osobowego, ale w mniejszym zakresie niż w przypadku komendanta miejskiego Policji. Komendant miejski Państwowej Straży Pożarnej zajmuje się organizacją krajowego systemu ratowniczo-gaśniczego na terenie miasta na prawach powiatu. Obejmuje ona w szczególności następujące czynności31:

1) opracowanie analiz zagrożeń oraz analiz zabezpieczenia operacyjnego;

2) opracowanie miejskiego planu ratowniczego;

27. A. Wierzbica, dz. cyt., s. 138.

28. Dz. U. z 2017 r. poz. 2067 z późn. zm.

29. W. Kotowski, Ustawa o Policji. Komentarz praktyczny, Warszawa 2012, s. 189.

30. Dz. U. z 2018 r. poz. 1313 z późn. zm.

31. B. Kurzępa, Ustawa z dnia 24 sierpnia 1991 r. o ochronie przeciwpożarowej. Komentarz, Toruń 2013, s. 147. 
3) ustalenie sieci podmiotów systemu i ich obszarów chronionych.

Zgodnie z art. 38a ust. 1 u.s.p., w celu realizacji zadań starosty w zakresie zwierzchnictwa nad powiatowymi służbami, inspekcjami i strażami oraz zadań określonych w ustawach w zakresie porządku publicznego i bezpieczeństwa obywateli, tworzy się komisję bezpieczeństwa i porządku. Właśnie zadania tego typu związane są z działalnością komend miejskich Policji oraz Państwowej Straży Pożarnej. Należy wskazać na art. 10 ustawy o Policji, zgodnie z którym komendant miejski Policji jest obowiązany do składania radzie miasta i prezydentowi miasta rocznych sprawozdań ze swojej działalności, a także informacji o stanie porządku i bezpieczeństwa publicznego. Z kolei art. 14 ustawy o Państwowej Straży Pożarnej daje prezydentowi miasta możliwość żądania od komendanta miejskiej straży pożarnej w każdym czasie informacji o stanie bezpieczeństwa ochrony przeciwpożarowej oraz ewentualnych zagrożeniach ${ }^{32}$. Zgodnie z art. 38a ust. 3 u.s.p. prezydent miasta na prawach powiatu i starosta powiatu graniczącego z takim miastem mogą utworzyć, w drodze porozumienia, wspólną komisję dla miasta na prawach powiatu oraz powiatu graniczącego z takim miastem. W takim przypadku prezydent miasta i starosta współprzewodniczą komisji.

Zgodnie z art. 80 ust. 2 ustawy z dnia 7 lipca 1994 r. - Prawo budowlane powiatowy inspektor nadzoru budowlanego wykonuje zadania

32. Ustawa..., s. 319.

33. Dz. U. z 2018 r. poz. 1202 z późn. zm.

34. T. Babiel, Nadzór budowlany. Kompetencje organów administracji, wzory, akty prawne, Warszawa 2001, s. 104. z zakresu nadzoru budowlanego ${ }^{33}$. Powiatowy inspektor nadzoru budowlanego, który wykonuje swoje zadania przy pomocy powiatowego inspektoratu nadzoru budowlanego, jest powoływany przez prezydenta miasta na prawach powiatu spośród co najmniej trzech kandydatów wskazanych przez wojewódzkiego inspektora nadzoru budowlanego. Jeżeli prezydent miasta nie powoła powiatowego inspektora nadzoru budowlanego w terminie 30 dni od dnia przedstawienia kandydatów, wojewódzki inspektor nadzoru budowlanego wskazuje spośród nich kandydata, którego starosta powołuje na to stanowisko. Odwołanie powiatowego inspektora budowlanego następuje w uzgodnieniu z wojewódzkim inspektorem nadzoru budowlanego lub na jego wniosek. Na gruncie tej regulacji prezydent miasta realizuje zespolenie osobowe w sposób o wiele szerszy niż w poprzednio omawianych przypadkach, choć wciąż musi on uwzględniać wskazania organu rządowej administracji zespolonej. Do właściwości powiatowego inspektora nadzoru budowlanego, jako organu pierwszej instancji, należą m.in. zadania w zakresie postępowania poprzedzającego rozpoczęcie robót budowlanych, czy też w zakresie oddawania do użytkowania obiektów budowlanych ${ }^{34}$. Część obiektów i robót budowlanych znajduje się poza właściwością powiatowego inspektora nadzoru budowlanego i tutaj właściwy jest wojewódzki inspektor nadzoru budowlanego. Przykładem jest kwestia działań wykonywanych na drogach publicznych krajowych i wojewódzkich, które przebiegają przez miasto na prawach powiatu.

Miasto. Pamięć i Przyszłość 3/2 (2018) ISSN 2543-621X 
Państwowy powiatowy inspektor sanitarny to organ rządowej administracji zespolonej w powiecie, co zresztą zostało wskazane wprost w ustawie z dnia 14 marca 1985 r. o Państwowej Inspekcji Sanitarnej35. Terytorialny obszar działania państwowego powiatowego inspektora sanitarnego oraz podległą mu stację sanitarno-epidemiologiczną określa rozporządzenie ministra właściwego do spraw zdrowia. Podobnie jak w przypadku powiatowego inspektora nadzoru budowlanego, w nazwie omawianego organu nie dokonuje się rozróżnienia ze względu na jego działalność w mieście na prawach powiatu. Państwowego powiatowego inspektora sanitarnego i jego zastępcę w mieście na prawach powiatu powołuje i odwołuje prezydent miasta za zgodą państwowego wojewódzkiego inspektora sanitarnego. Państwowy powiatowy inspektor sanitarny przedstawia radzie miasta, przynajmniej raz w roku, informację o stanie bezpieczeństwa sanitarnego miasta na prawach powiatu.

\section{Zakończenie}

Analizując poruszone w tekście kwestie, można dostrzec, iż funkcjonowanie administracji zespolonej w mieście na prawach powiatu nie różni się w znacznym stopniu od modelowego, ustawowego ujęcia powiatowej administracji zespolonej. Różnice wynikają przede wszystkim ze specyfiki miasta na prawach powiatu jako jednostki samorządu terytorialnego będącej kombinacją kompetencji i ustroju gminy oraz powiatu. Zakres zespolenia miejskich służb, inspekcji i straży jest tak samo determinowany przez ustawy szczególne, jak ma to miejsce w przypadku zespolenia ze starostą. W przypadku służb związanych z utrzymaniem bezpieczeństwa i porządku publicznego, owo zespolenie podlega pewnemu ograniczeniu. Wskazane aspekty działalności administracji zespolonej w mieście na prawach powiatu, ze względu na ograniczone ramy opracowania, tylko w części ukazują głębię tematu oraz rozbudowanie państwowych struktur administracyjnych na poziomie samorządu terytorialnego.
Miasto. Pamięć i Przyszłość 3/2 (2018) ISSN 2543-621X
35. Dz. U. z 2017 r. poz. 1261 z późn. zm. 


\section{Literatura}

- T. Babiel, Nadzór budowlany. Kompetencje organów administracji, wzory, akty prawne, Warszawa 2001.

- J. Boć, Prawo administracyjne, Wrocław 2010.

- B. Dolnicki, Samorzą terytorialny, Warszawa 2016.

- W. Kotowski, Ustawa o Policji. Komentarz praktyczny, wyd. 3., Warszawa 2012

- B. Kurzępa, Ustawa z dnia 24 sierpnia 1991 r. o ochronie przeciwpożarowej. Komentarz, Toruń 2003.

- I. Lewandowska-Malec, Samorzad terytorialny w Polsce: zarys wykładu, kazusy, wybór źródet, Kraków 2007.
- Powiat. Z teorii, kompetencje, komentarz, red. J. Boć, Wrocław 2001.

- Prawo administracyjne. Część ogólna, red. M. Chmaj, Warszawa 2007.

- Ustawa o samorządzie powiatowym. Komentarz, red. B. Dolnicki, Kraków 2005.

- A. Wierzbica, Miasto na prawach powiatu. Zagadnienia ustrojowe, Warszawa 2006.

- J. Zimmermann, Prawo administracyjne, Warszawa 2014. 